Hydrol. Earth Syst. Sci., 12, 1201-1209, 2008

www.hydrol-earth-syst-sci.net/12/1201/2008/

(C) Author(s) 2008. This work is distributed under

the Creative Commons Attribution 3.0 License.

\title{
Discharges of past flood events based on historical river profiles
}

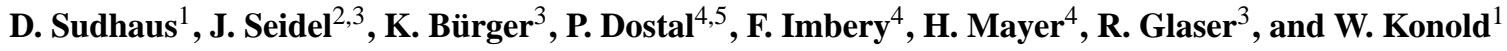 \\ ${ }^{1}$ Institute for Landscape Management, Albert-Ludwigs-University Freiburg, Germany \\ ${ }^{2}$ Institute for Hydraulic Engineering, Department of Hydrology and Geohydrology, Universität Stuttgart, Germany \\ ${ }^{3}$ Department of Physical Geography, Albert-Ludwigs-University Freiburg, Germany \\ ${ }^{4}$ Meteorological Institute, Albert-Ludwigs-University Freiburg, Germany \\ ${ }^{5}$ Department of Computer Science, Environmental Modelling Group EMG, University of Mainz, Germany
}

Received: 20 December 2007 - Published in Hydrol. Earth Syst. Sci. Discuss.: 12 February 2008

Revised: 29 July 2008 - Accepted: 29 July 2008 - Published: 8 October 2008

\begin{abstract}
This paper presents a case study on the estimation of peak discharges of extreme flood events during the 19th century of the Neckar River located in south-western Germany. It was carried out as part of the BMBF (German Federal Ministry of Education and Research) research project RIMAX (Risk Management of Extreme Flood Events). The discharge estimations were made for the 1824 and 1882 flood events, and are based on historical cross profiles. The 1-D model Hydrologic Engineering Centers River Analysis System (HEC-RAS) was applied with different roughness coefficients to determine these estimations. The results are compared (i) with contemporary historical calculations for the 1824 and 1882 flood events and (ii) in the case of the flood event in 1824, with the discharge simulation by the water balance model LARSIM (Large Area Runoff Simulation Model). These calculations are matched by the HEC-RAS simulation based on the standard roughness coefficients.
\end{abstract}

\section{Introduction}

The reconstruction of historical flood events is an important part of modern flood risk management. For planners and engineers, extreme flood events are of high interest, although these events are very rare in observational records (Enzel et al., 1993). The discharge estimation for extreme historical flood events extends existing discharge data series and improves statistical calculations, for example for the determination of return periods as well as for the better assessment

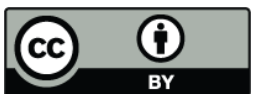

Correspondence to: J. Seidel

(jochen.seidel@iws.uni-stuttgart.de) of extreme flood events. The identification and quantification of historical flood events also provides answers to the question as to whether or not the frequency and magnitude of floods have increased during the past few centuries. For a well-founded flood-frequency analysis, the magnitude of the peak discharge of historical floods must be quantified (Cook, 1987). Therefore, the inclusion of historical data considerably improves the reliability of calculations of the return periods for extreme flood events (IKSE, 2004; Payrastre et al., 2005).

The occurence of severely damaging floods in Europe (e.g. Oder 1997, Elbe 2002 and 2006, Danube 2006) resulted in a general interest in increasing flood risk and flood risk management. Furthermore, as a result of regional climate change, the intensity of rainfall is likely to rise in Central Europe. Therefore, the flood risk is expected to increase in the future for specific regions such as Northern, Central and Eastern Europe (KLIWA, 2003; IPCC, 2007). Additionally, the number of people and economic assets located in flood endangered areas is expected to further increase, resulting in higher damage potential. Flood risk mapping can reduce potential economic and health damages and raise the risk awareness of the general population.

Peak discharges are the basis for flood area mapping. Flood level marks alone give insufficient information about the severity of a flood due to the fact that hydraulic engineering may have influenced the stage-discharge relation over the course of time. Additionally, historical calculations of discharge often appear not to be reliable (Pohl, 2007). In historical times as well as today, the data for the largest floods have frequently been indirect post-flood estimations. This is due to the fact that conventional stream gauge stations have great difficulties to accurately record extreme floods, since these

Published by Copernicus Publications on behalf of the European Geosciences Union. 


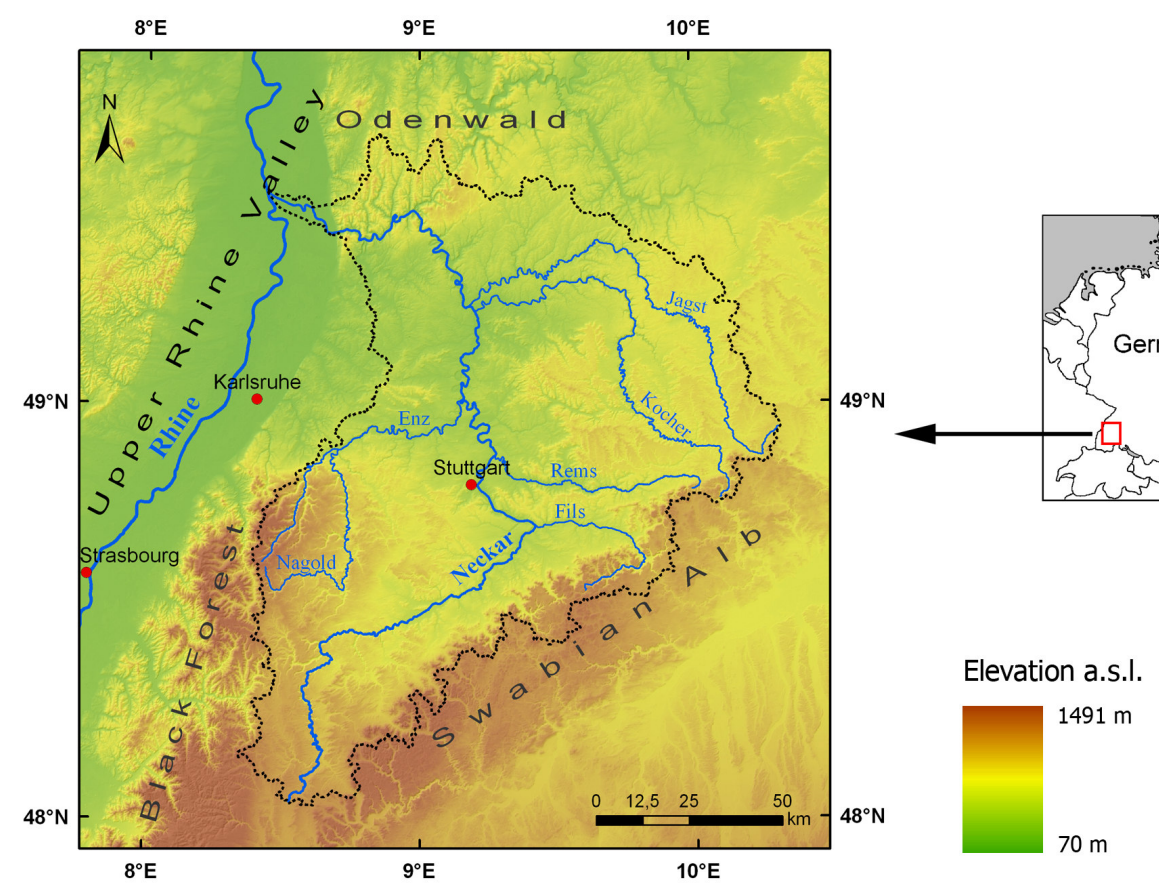

Fig. 1. Study area including the Neckar catchment (dotted black outline).

gauges may have been inundated, damaged or destroyed during the flood (Benito et al., 2004).

Discharge measurements during flood conditions are very important, but were explicitly difficult to determine in historical times. Between 1860 and 1900, the effort to improve discharge measurements was increased. An example of this fact was the development of open channel flow resistance equations (Hager, 1994). Many of the historical discharge calculations cited in this paper originate from that time period. Therefore, the informational value of these historical data must be examined before they can be used for statistical calculations such as return times.

Bürger et al. (2006) calculated the discharge of 1824 extreme flood event along the Neckar River using historical meteorological measurements and the water balance model LARSIM (Ludwig and Bremicker, 2006). Kidson et al. (2002), Barriendos and Coeur (2004) and Thorndycraft et al. $(2005,2006)$ used historical flood marks and recent cross sections of bedrock channels for the estimation of palaeodischarges.

In the presented study, the discharge reconstruction of the extreme floods in 1824 and 1882 along the Neckar and its tributaries is tested using historical cross profiles and water levels with the hydraulic model HEC-RAS (Hydrologic Engineering Center, 2005). Furthermore, the results from the 1824 flood are compared with historical discharge calculations obtained by a hydrometeorological simulation with the LARSIM model (Bürger et al., 2006).

\section{Study area}

The Neckar River with a catchment area of $14000 \mathrm{~km}^{2}$ is located in the south-western part of Germany and is a tributary of the Upper Rhine (Fig. 1). The Neckar has a length of $367 \mathrm{~km}$ and originates in the Eastern Black Forest at an elevation of $706 \mathrm{~m}$ a.s.l. The river passes through the cities of Tübingen, Stuttgart, Heilbronn, Heidelberg and Mannheim, where it discharges into the Rhine. The main tributaries of the Neckar are the Rivers Fils, Rems, Enz, Kocher and Jagst. The Neckar catchment ranges from 78 to $1020 \mathrm{~m}$ a.s.l. (Fig. 1) and the local orography plays an important influencing role in the local precipitation. Today, $202.5 \mathrm{~km}$ of the Neckar are navigable between Plochingen and Mannheim, which is located at the mouth of the river. Together with the Rhine and Main Rivers, the Neckar is one of the three main waterways in the German federal state of Baden-Württemberg.

During the 19th century, the land of the Neckar catchment was divided between five territorial states: The Grand Duchy of Baden, the Kingdom of Württemberg, the Prussian Province of Hohenzollern, the Grand Duchy of Hesse, and the Kingdom of Bavaria (Fig. 2). The main channel of the Neckar River was situated in the former Grand Duchy of Baden and the former Kingdom of Württemberg. The latter three states only held minor percentages of the catchment area. Therefore, most of the hydraulic engineering measures of the Neckar were primarily carried out and documented by these two states. 
Table 1. Historical sources for cross profiles along the Neckar. Cross profile numbers $A=1824, B=1882$.

\begin{tabular}{ccclrr}
\hline River/Administration & Data Source & & Cross Profile & $\mathrm{km}$ \\
\hline \multirow{2}{*}{ Neckar / Baden } & General State Archive & A1 & & Obrigheim I & 82.50 \\
& Karlsruhe (year unknown) & A 2 & & Obrigheim II & 84.00 \\
\hline & Administrative reports & A 3 & B 1 & Gemmrigheim & 137.04 \\
& (Königliches Ministerium & A 4 & B 2 & Münster & 186.47 \\
& des Innern 1896) & & & & \\
& City Archive Stuttgart & A 5 & & Bad Cannstatt I & 187.00 \\
& $(1877)$ & A 6 & & Bad Cannstatt II & 187.22 \\
Neckar / Württemberg & A 7 & & Bad Cannstatt III & 188.34 \\
& & A8 & & Plochingen & 212.04 \\
& & & B 3 & Neckartenzlingen & 234.43 \\
& Administrative reports & & B 4 & Tübingen & 253.60 \\
& (Königliches Ministerium & & B 5 & Horb & 288.30 \\
& des Innern 1896) & B 6 & Aistaig & 313.20 \\
& & B 7 & Oberndorf & 317.90 \\
& & B 8 & Epfendorf & 327.23 \\
& & B 9 & Rottweil & 344.00 \\
\hline
\end{tabular}

The first gauging station at the Neckar River was installed in Heilbronn in 1827 (Centralbureau für Meteorologie und Hydrographie, 1889). Starting in 1881, continuous and systematic measurements of the water levels were carried out at six gauging stations along the Neckar River (StatistischTopographisches Bureau, 1883). At present, 17 gauging stations are installed along the main channel of the Neckar. In the lower course of the Neckar River, between Heidelberg and Mannheim, the mean, minimum and the maximum flood discharges are $145 \mathrm{~m}^{3} \mathrm{~s}^{-1}, 42 \mathrm{~m}^{3} \mathrm{~s}^{-1}$ and $1150 \mathrm{~m}^{3} \mathrm{~s}^{-1}$, respectively (LfU, 2005).

\section{Material and methods}

Different sources such as archive records and administrative reports from 19th century authorities where examined to obtain suitable river cross profiles (Table 1). A number of cross profiles including various hydraulical parameters were generated during the 19th century through the implementation of hydro-engineering measures to achieve better navigability and technical flood risk management throughout the Neckar River system. All historical profiles chosen for the discharge calculations in this study meet the following criteria:

- Contain information about the water level

- Specify the elevation (water level and/or river bed)

- Specify the channel slope of the river section

- Water levels must not exceed the hight of the cross profile

- Have no bridges or weirs (to avoid backwater effects)

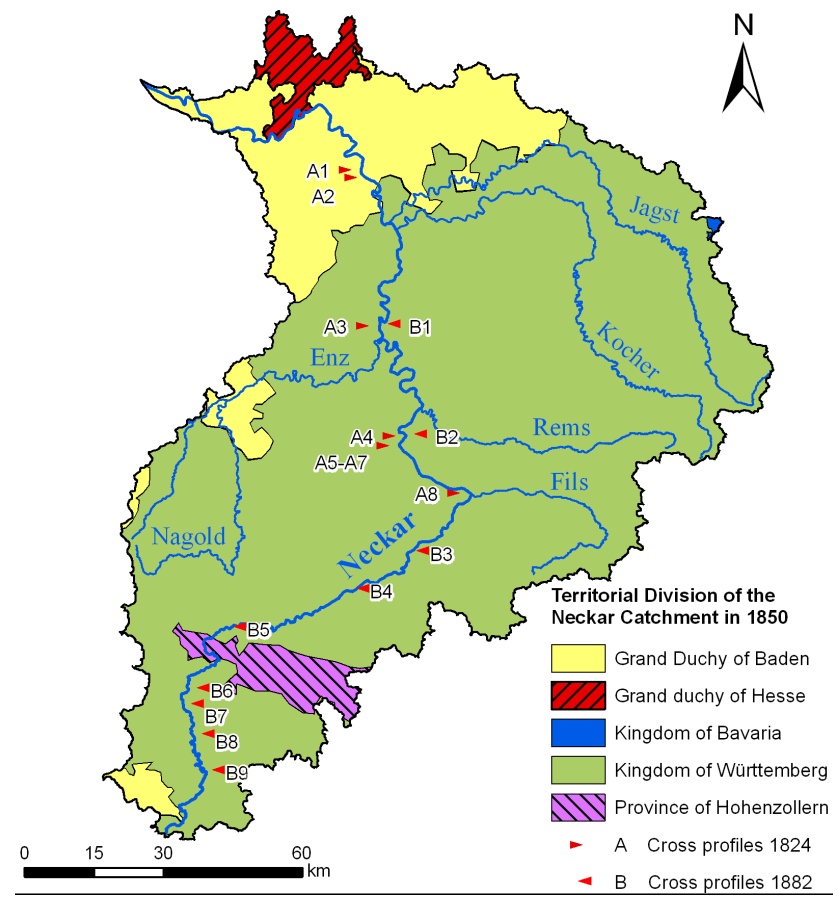

Fig. 2. Historical administrative districts in the Neckar catchment area and sites of the cross profiles (numbers according to Table 1).

For the flood events of 1824 and 1882, discharges were calculated using eight and nine different river cross profiles, respectively, along the Neckar River (Fig. 2 and Table 1). In the case of the 1824 flood event, the profiles used to calculate the discharges are situated between the cities of Plochingen (historical river $\mathrm{km} \mathrm{212}$ ) and Obrigheim (river $\mathrm{km} 82$ ), which is located downstream of last major inflows into the Neckar River (Rivers Kocher and Jagst at river km 98 and 
Table 2. Assigned Manning's $n$ values for hydraulic modelling.

\begin{tabular}{lccc}
\hline $\begin{array}{l}\text { Surface } \\
\text { description }\end{array}$ & $\begin{array}{c}\text { Minimum } \\
\text { Manning's } \\
n \text { value }\end{array}$ & $\begin{array}{c}\text { Standard } \\
\text { Manning's } \\
n \text { value }\end{array}$ & $\begin{array}{c}\text { Maximum } \\
\text { Manning's } \\
n \text { value }\end{array}$ \\
\hline Channel & 0.025 & 0.03 & 0.04 \\
Grass & 0.025 & 0.035 & 0.05 \\
Trees & - & - & 0.8 \\
\hline
\end{tabular}

100). Therefore, the cross profiles at Obrigheim are representative for the lower course of the Neckar. For the Stuttgart section of the Neckar River, three suitable and exceptionally detailed cross profiles (profiles A5-A7 in Table 1 and Fig. 2) were found in a historical record in the City Archive of Stuttgart (1877).

The cross profiles for the 1882 flood event are located between the cities of Rottweil (river km 344) and Gemmrigheim (river $\mathrm{km} \mathrm{137).} \mathrm{For} \mathrm{this} \mathrm{flood,} \mathrm{there} \mathrm{is} \mathrm{no} \mathrm{informa-}$ tion available about the discharges in the lower course of the Neckar after the inflow of the Rivers Kocher and Jagst. However, at two profiles (Münster and Gemmrigheim, Table 1) there are water stage data available for both flood events.

The selected cross profiles were digitized and the distances were converted from historical units to SI-units. The discharge calculations were carried out using the 1-D hydraulic model HEC-RAS 3.1.3 (Hydrologic Engineering Center, 2005). Previously, this model has been successfully used in palaeoflood studies (O'Conner and Webb, 1987; Kidson et al., 2002; Benito et al., 2004; Thorndycraft et al., 2006). For the calculation of the discharges, the single cross profiles were regionalized and the particular river slopes were derived from the historical longitudinal profile of the Neckar River.

The most uncertain variable of this calculations is the roughness coefficient (Manning's $n$; Cook, 1987). For example, a 50\% error in the roughness coefficient results in a maximum error of $25 \%$ in the upper end of the rating curve (Sauer et al., 1984). For a difference of 50\% in the roughness coefficient, Kidson et al. (2002) calculated a discharge error of $40 \%$ for a palaeoflood in a bedrock river. The channel conditions during the 1824 and 1882 floods (scour, fill, debris), however, are not known (Cook, 1987). For the adjacent flood plain, the uncertainty factor is higher due to changes in the vegetation cover. For such flood plains where the historical land use is not known, the uncertainty factor could be especially high. Therefore, a range of roughness coefficients (Manning's $n$ ) obtained by default values was used in this study (Table 2). For the river bed, a standard value of 0.03 was used, which corresponds to the roughness coefficient found in historical hydraulic engineering documents. For flooded areas outside of the river bed, where no land use information or roughness coefficients were available, a high grass cover vegetation or the upper limit of short grass cover with a roughness coefficient of 0.035 for the standard value was assumed for the roughness coefficient.

The standard Manning's $n$ for the river bed is nearly the same as that as mentioned in historical administrative reports for tributaries of the Neckar River (Königliches Ministerium des Innern, 1901). The specified roughness coefficients in historical times were calculated with the Ganguillet-Kutter equation:

$$
v=\frac{\frac{1}{n}+23+\frac{0,00155}{J}}{1+\left(23+\frac{0,00155}{J}\right) \frac{n}{\sqrt{R}}} \sqrt{R J}
$$

where $v$ = flow velocity, $n=$ roughness coefficient, $R=$ hydraulic radius and $J=$ water surface slope (Königliches Ministerium des Innern, 1896). A calibration of the model was not possible because the stage-discharge relations are not known for the historical cross profiles. The discharges were calculated as subcritical flow conditions. The HECRAS model uses the Mannig-Strickler equation for discharge estimation. In contrast, the historical discharges were calculated according to Harlacher's graphic method (Königliches Ministerium des Innern, 1896).

Because the profiles are not direcly linked to gauging stations, the indicated historical water level could potentially portray the wash of the waves (energy head) as the maximum hight and therefore overestimate the actual maximum water level. Therefore, as shown in the diagrams (Figs. 36), discharge values were also computed by using the energy line (EL) with the standard roughness. The discharges using the water surfaces (WS) were computed with three different roughness values (Table 2).

\section{Discharge calculation results for the Neckar River for the 1824 and 1882 floods}

\subsection{Examples from greater Stuttgart}

\section{Stuttgart-Cannstatt profile}

A cross profile and the stage-discharge in Stuttgart (Neckar River) is presented in Fig. 3. The flow discharge calculated on the basis of the standard Manning's $n$ for 1824 ranges from $1610 \mathrm{~m}^{3} \mathrm{~s}^{-1}$ (energy line) to $2070 \mathrm{~m}^{3} \mathrm{~s}^{-1}$ (Fig. 5). Since the cross profile originates from the year 1877, there is no water stage available for the 1882 flood event.

\section{Münster profile}

Figure 4 displays the cross profile of the Neckar at Münster (5 km downstream of Stuttgart) at historical river km 186.47 and the corresponding stage-discharge curve determined with HEC-RAS. The figure shows the difference between the energy line and the water level as stage-discharge relations for the 1824 and the 1882 flood. The 1824 flow discharge ranges from $1800 \mathrm{~m}^{3} \mathrm{~s}^{-1}$ (EL) to $2170 \mathrm{~m}^{3} \mathrm{~s}^{-1}$ (WS). 


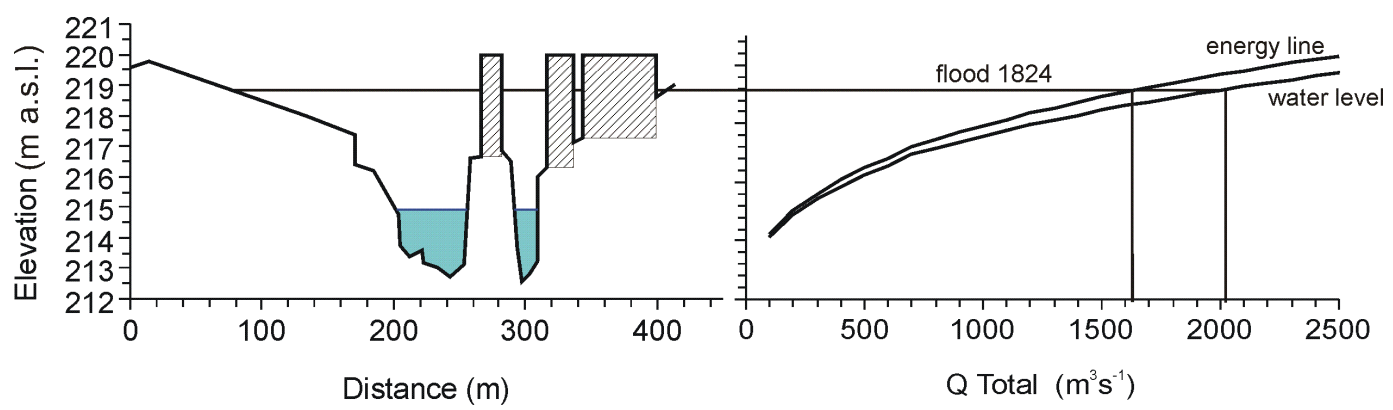

Fig. 3. Cross profile A5 from Stuttgart (Neckar River) with the stage-discharge curve and energy line (standard Manning's $n$ ) during the highest stage of the 1824 flood.
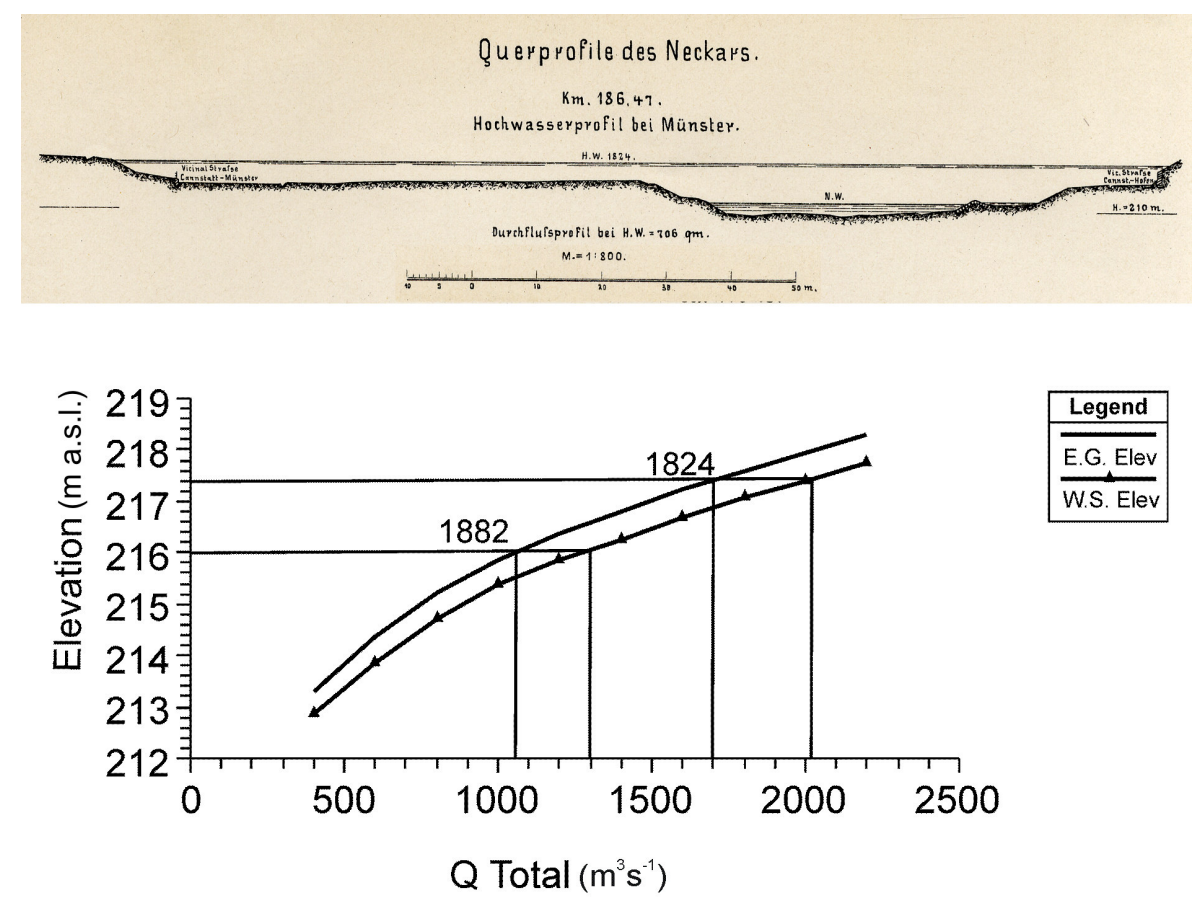

Fig. 4. Historical cross profile at Münster (A4/B2) (Königliches Ministerium des Innern, 1896) with the stage-discharge curve and energy line (standard Manning's $n$ ), indicated water stages for the floods of 1824 and 1882.

The discharges computed with high and low roughness values range from 1430 to $3100 \mathrm{~m}^{3} \mathrm{~s}^{-1}$ (both for the WS). The historical discharge determined by the official water authorities at the time is $1700 \mathrm{~m}^{3} \mathrm{~s}^{-1}$ (Königliches Ministerium des Inneren, 1896). The calculated discharge for the 1882 flood event using the standard Manning's $n$ ranges from $1140 \mathrm{~m}^{3} \mathrm{~s}^{-1}$ (EL) to $1500 \mathrm{~m}^{3} \mathrm{~s}^{-1}$ (WS). The historical calculated discharge amount is $1250 \mathrm{~m}^{3} \mathrm{~s}^{-1}$, which falls within the calculated ranges. The calculations using the minimum and maximum Manning's $n$ values results in a discharge of $910 \mathrm{~m}^{3} \mathrm{~s}^{-1}$ and $2100 \mathrm{~m}^{3} \mathrm{~s}^{-1}$, respectively.

\subsection{Overview of the results obtained for the Neckar River}

Figure 5 shows the results of the discharge calculations using HEC-RAS for the 1824 flood between river $\mathrm{km} 80$ and 220 , and the historical calculations. In addition, the simulated discharges from Bürger et al. (2006) for the 1824 flood event are depicted; the 1824 flood is the most severe event within the last 500 years. Also, the discharge values for the design extreme flood (EHQ), determined by the local environmental agency, are shown (LfU, 2005). Since there are no documented water stages for any cross profiles further upstream, this particular river section was omitted in Fig. 5a. Due to the short distances between the cross profiles at Stuttgart (km 180) this section is magnified (Fig. 5b). 


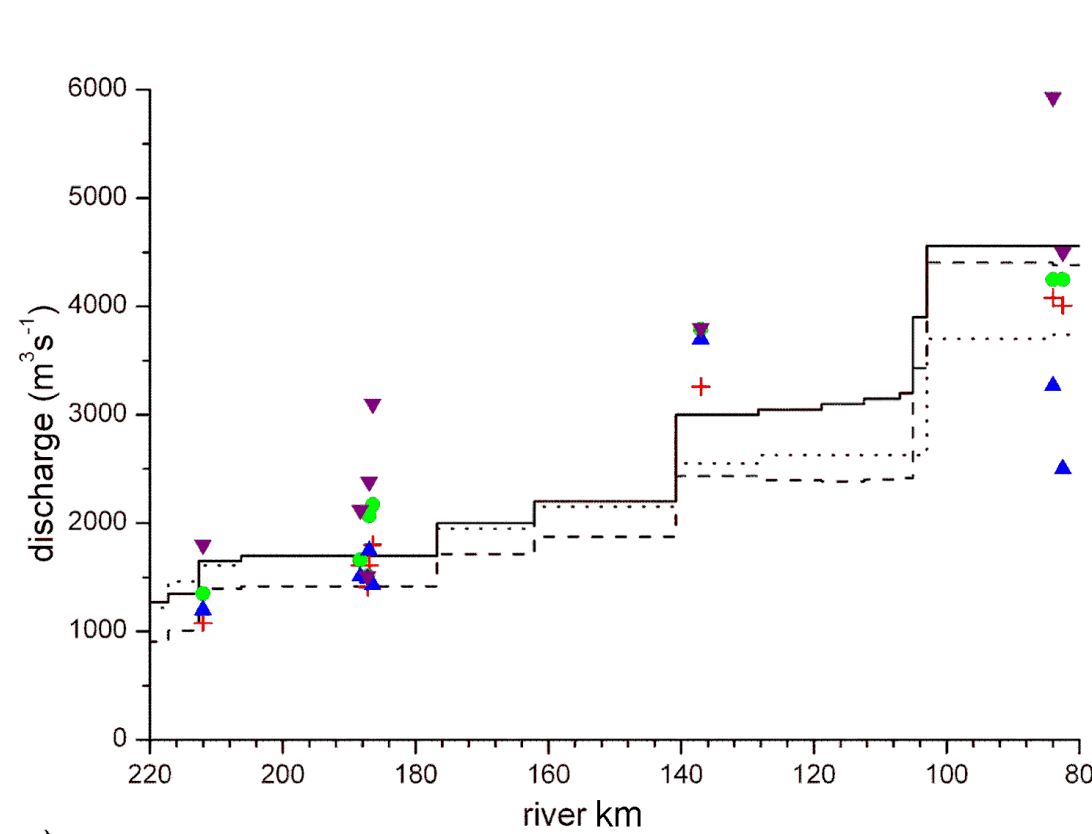

a)

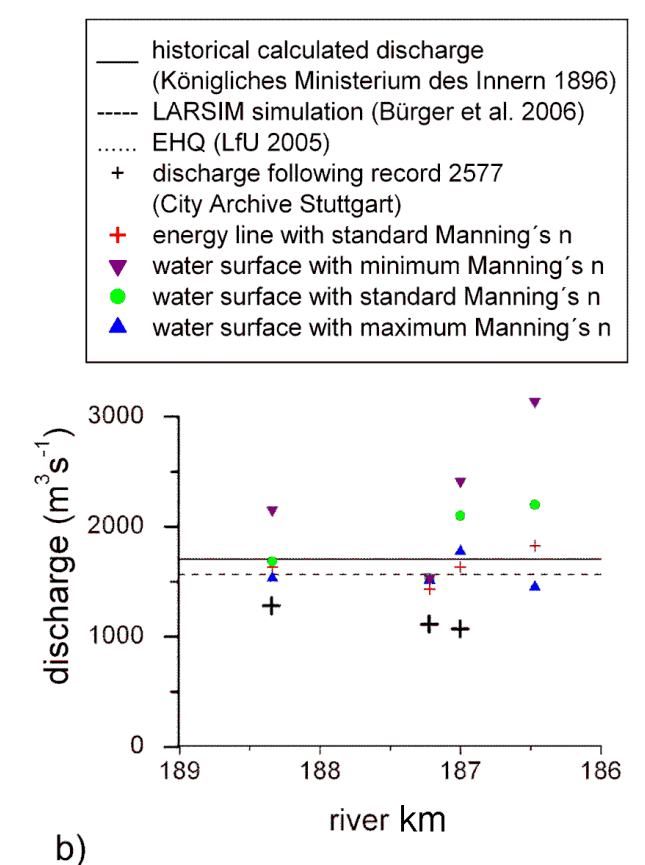

Fig. 5. (a) Discharges for the Neckar during the 1824 flood event from historical administrative documents (Königliches Ministerium des Innern, 1896), discharges simulated with historical cross profiles, LARSIM simulation by Bürger et al. (2006) and the current EHQ (LfU, 2005); (b) magnification of the river section in Stuttgart (km 189-186).

For this section, the results from the HEC-RAS simulation using the EL and WS with standard roughness parameters match the historical calculations. Generally, this simulation accuracy applies also for the whole Neckar River (Fig. 5a), except for the profile at Gemmrigheim (A3, river km 137), where all HEC-RAS dicharge simulations are much higher than the discharges from historical sources and the LARSIM model.

Figure 6 shows the results of the discharge calculations using HEC-RAS for the 1882 flood in comparison with the historical calculations. Since the availability of historical data in the former Kingdom of Württemberg is generally better for the second half of the 19th century, the profiles for this flood event are distributed more evenly along the Neckar River. In contrast, there are no cross profiles available for the river section in the former Grand Duchy of Baden, resulting in the discontinuation of the diagram at river $\mathrm{km} \mathrm{100.} \mathrm{Except} \mathrm{for}$ the profiles B8 and B9 (Table 1) in the upper course of the Neckar, where the flow area is relatively small, the discharges derived with HEC-RAS using the EL and WS with standard Manning's $n$ correspond closely with the values from the administrative reports (Fig. 6).

\section{Discussion of the results}

Discharge calculations from four different sources are available for three cross profiles in Stuttgart: a. record 2577 from the City Archive of Stuttgart from 1877

b. administrative report from the Interior Ministry of the Kingdom of Württemberg (Königliches Ministerium des Innern, 1896)

c. discharge simulation from the run-off model LARSIM (Bürger et al., 2006, 2007)

d. calculations from HEC-RAS based on historical profiles from record 2577, City Archive Stuttgart

Compared to the historical calculations for 1824 (a) at Stuttgart (Fig. 5, river km 189-187, $1370 \mathrm{~m}^{3} \mathrm{~s}^{-1}$ ), the streamflow from all HEC-RAS simulation runs (d) as well as the results from LARSIM (c) and the discharges from the administrative report (b) are higher. This shows that a critical assessment of historical sources and records is necessary and that it is important to analyse all available historical data. The calculations from the administrative reports (b), with a value of $1700 \mathrm{~m}^{3} \mathrm{~s}^{-1}$ for this site, are similar to the results of the present study $\left(1410-2380 \mathrm{~m}^{3} \mathrm{~s}^{-1}\right)$ and identical with the EHQ (LfU, 2005). Bürger et al. (2006) reconstructed the hydrometeorological conditions of the 1824 flood event and simulated the resulting discharges with the current hydrological conditions of the Neckar River system (c). The flood discharge for this river section is approximately $1420 \mathrm{~m}^{3} \mathrm{~s}^{-1}$ and thus matches the value simulated with HEC-RAS using 


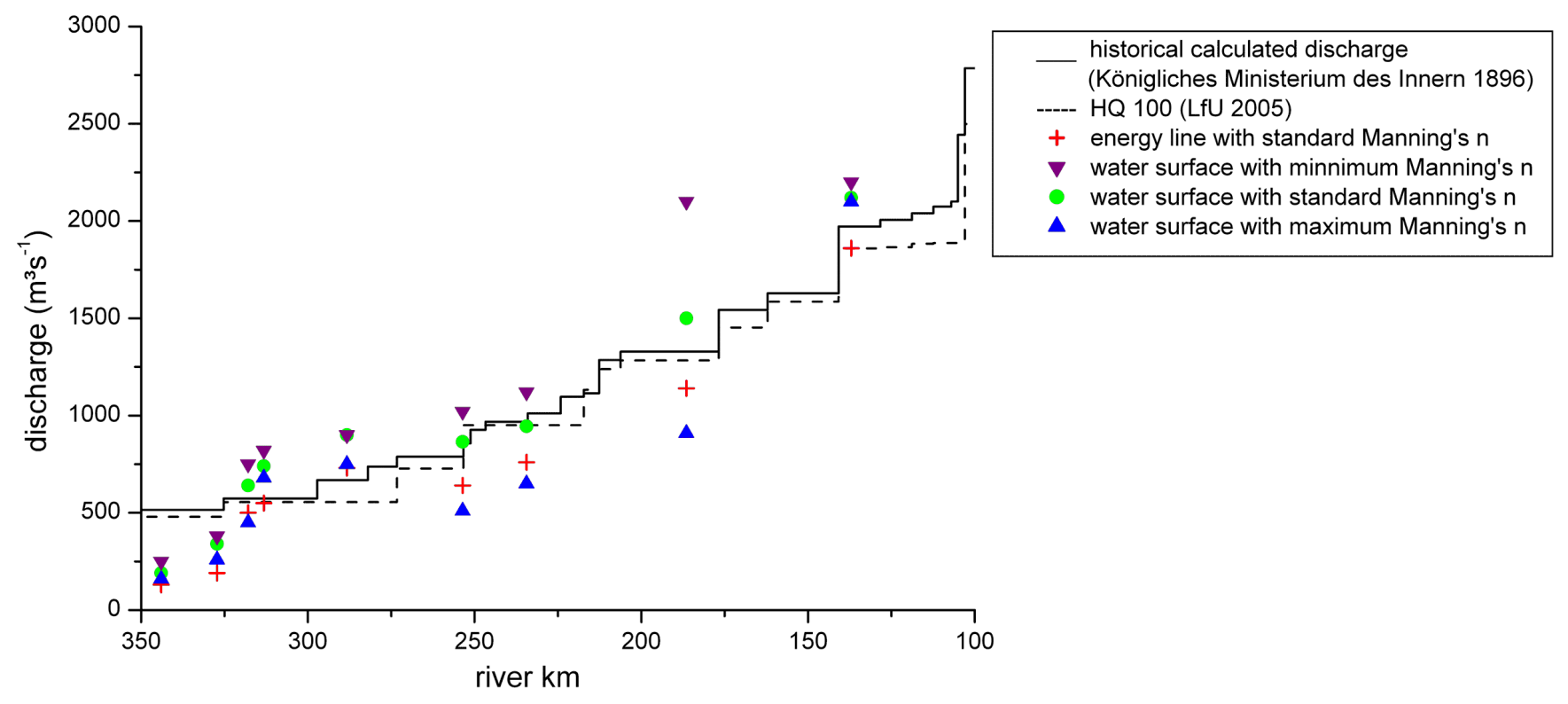

Fig. 6. Discharges for the Neckar during the flood of 1882 from historical administrative documents (Königliches Ministerium des Innern, 1896), discharges simulated with historical cross profiles and the current HQ 100 (LfU, 2005).

the energy line and standard Manning's $n$ (d). Generally, the 1824 flood discharges simulated with LARSIM tend to underestimate the actual peak flood discharges, because the input data for this simulation was only available in daily resolution.

For the cross profile at Münster (river km 186), Bürger et al. (2006) determined a discharge of approximately $1700 \mathrm{~m}^{3} \mathrm{~s}^{-1}$. Based on the chosen roughness values (Table 2), the discharge values calculated with HEC-RAS were found to be in a range of 1430 to $3100 \mathrm{~m}^{3} \mathrm{~s}^{-1}$. Using the energy line and standard Manning's $n$, a value of $1800 \mathrm{~m}^{3} \mathrm{~s}^{-1}$ is achieved, which is in line with the LARSIM results. In comparison, the current HQ 100 determined by the water authorities for this site is approximately $1200 \mathrm{~m}^{3} \mathrm{~s}^{-1}$ (LfU, 2005). The two discharge amounts for the 1824 flood event obtained from historical cross profiles in the Grand Duchy of Baden range from 2500 to $5900 \mathrm{~m}^{3} \mathrm{~s}^{-1}$. The discharge amount using the water level and standard roughness is $4250 \mathrm{~m}^{3} \mathrm{~s}^{-1}$ for both profiles and, using the energy line, 4010 and $4080 \mathrm{~m}^{3} \mathrm{~s}^{-1}$, respectively. Thus, the flood discharge at this site was far higher than the current EHQ of $3600 \mathrm{~m}^{3} \mathrm{~s}^{-1}$ for the nearest current gauging station near Ebersbach-Rockenau at river km 60 (LfU, 2005). This difference as well as the historical documentation reflects the extreme magnitude of the 1824 flood event, especially in the lower course of the Neckar River (Bürger et al., 2006). The flood of 1824 was the most extreme event along the Neckar River within the last 500 years and reached its highest water levels after the inflow of the River Enz at km 140. Based on the presented results, the discharge amounts for the 1824 flood reported in the historical sources by the lo- cal water authorities in the former Kingdom of Württemberg (Königliches Ministerium des Innern, 1896) and the Grand Duchy of Baden (Centralbureau für Meteorologie und Hydrographie, 1993) are plausible.

Unfortunately there were no historical cross profiles of the corresponding water levels available for the 1882 flood event for the lower section of the Neckar River in the Grand Duchy of Baden. The only available historical source (Centralbureau für Meteorologie und Hydrographie, 1893) states a discharge of approximately $3000 \mathrm{~m}^{3} \mathrm{~s}^{-1}$ for the city of Heidelberg (river km 26) which is slightly higher than the current HQ 100 (LfU, 2005) and seems to correspond to the intensity of the flood in this river section. Throughout the course of the Neckar River, the flood event of 1882 reached the intensity of the current HQ 100 and was lower than the flood in 1824.

For the 1824 flood, the time span between the actual flood event and the time of the survey, when the cross profiles were mapped, reaches up to 50 years, depending on the source of the cross profiles. Hence, we have to take into account that the historical discharge values for 1824 were approximated and the water levels were reconstructed since there were no gauging stations in operation at the time. Therefore, the indicated water level also could be related to the energy level of the cross profile, which Thorndycraft et al. (2006) also assumed for estimating palaeodischarges from sediment records. Figure 5 shows that there is no significant correlation between EL or WS and the historical calculated discharges or the LARSIM results, respectively. Therefore, both have to be taken into account when evaluating historical water levels which were not derived at gauging stations. This is also the case of the 1882 flood event, although the discharge 
calculations were generally more sophisticated at this time, given there were several gauging stations in service. Nevertheless, the results allow for no clear statement as to whether the EL or WS is the more suitable value to use in discharge calculations based on historical data. Concerning the roughness parameters, the standard Manning's $n$ produces the most feasible results. Both methods for discharge calculation used in this study produce comparable results, on the one hand the simulation with LARSIM based on runoff with the present Neckar catchment and stream course situation and on the other hand the hydraulic modelling with HEC-RAS by water stages on historical cross profiles. This fact shows that the changes in the river morphology of the Neckar, such as meander cut-offs and bank fixations, which where carried out increasingly from the 19th century onwards, don't seem to have a substantial influence on the peak discharges when regarding extreme floods on larger scales.

\section{Conclusions}

This paper completes the historical flood analysis presented by Bürger et al. $(2006,2007)$ for the Neckar River. The presented study shows that it is generally possible to estimate the discharge of historical floods using historical documents and to obtain details about the course and quality of a flood event. The results of this study, the historical discharges as well as the LARSIM results are comparable, so the presented method can be used to verify historical discharge calculations and to obtain the discharges when no historical calculations are available. By using various historical profiles, it is possible to analyze large parts of a river course and thereby recognize possible systematic errors in the sources. Hence, it is not reliable to use only a few cross profiles or data sources within a river system to obtain reliable information concerning a historical flood.

The 1824 flood event was the most extreme flood in large parts of the Neckar River, but the magnitude of the flood is not reflected by the current EHQ. Therefore, the results from this study can contribute towards better flood proctection as well as more reliable hazard assement in river catchments; the knowledge about historical flood processes leads to a better understanding of flood processes.

Acknowledgements. The authors would like to thank the BMBF (German Federal Ministry of Education and Research) and the Federal State Ministry of Science, Research and Arts in BadenWürttemberg for their funding. Furthermore, the authors thank the General State Archive Karlsruhe and the City Archive Stuttgart for the permission to scan and publish their historical records. We would also like to thank T. Strahl and M. Lynch for their proof-reading, and corrections and two anonymous referees and the editor for their helpful comments, which allowed us to improve the manuscript.

Edited by: A. Gelfan

\section{References}

Barriendos, M. and Coeur, D.: Flood data reconstruction in historical times from non-instrumental sources in Spain and France, in : Systematic, Palaeoflood and Historical Data for the Improvement of Flood Risk Estimation, edited by: Benito, G. and Thorndycraft, V. R., CSIC, Madrid, Spain, 29-42, 2004.

Benito, G., Lang, M., Barriendos, M., Llasat, M. C., Francés, F., Ouarda, T., Thorndycraft, V. R., Enzel, Y., Bardossy, A., Coeur, D., and Bobée, B.: Use of Systematic, Palaeoflood and Historical Data for the Improvement of Flood Risk Estimation, Review of Scientific Methods, Nat. Hazards, 31, 623-643, 2004.

Bürger, K., Dostal, P., Seidel, J., Imbery, F., Barriendos, M., Mayer, H., and Glaser, R.: Hydrometeorological reconstruction of the 1824 flood event in the Neckar River basin (southwest Germany), Hydrol. Sci. J., 51, 864-877, 2006.

Bürger, K., Seidel, J., Glaser, R., Sudhaus, D., Dostal, P., and Mayer, H.: Extreme floods of the 19th century in southwest Germany, Houille Blanche, 1/2007, 67-73, 2007.

Centralbureau für Meteorologie und Hydrographie: Die Wassermengen der fliessenden Gewässer im Großherzogthum Baden, Beiträge zur Hydrographie des Grossherzogthums Baden, 8. Heft, Berlin, Germany, 1893.

Centralbureau für Meteorologie und Hydrographie: Der Rheinstrom und seine wichtigsten Nebenflüsse, Karlsruhe, Germany, 1889.

City Archive Stuttgart: Cannstatt Verwaltungsakten. Hochwasser (u. Überschwemmungen) 1824-1884-1894, mit Situationsplänen und Zeichnungen zu den Überschwemmungen 1824 und 1845, City Archive Stuttgart, Germany, record 2577, 1877.

General State Archive Karlsruhe: Querprofile des Neckars unterhalb Neckarsteinach und unterhalb Diedesheim. Generallandesarchiv Karlsruhe, record G Wasserbaupläne 1Ab2Nr.4, Blätter 2+4, unknown date.

Cook, J. L.: Quantifying peak discharges for historical floods, J. Hydrol., 96, 29-40, 1987.

Enzel, Y., Ely, L. L., House, P. K., Baker, V. R., and Webb, R. H.: Palaeoflood evidence for a natural upper bound to flood magnitudes in the Colorado River basin, Water Resour. Res., 29, $2287-$ 2297, 1993.

Hager, W.: Die historische Entwicklung der Fließformel, Schweizer Ingenieur und Architekt, 9, 123-133, 1994.

Hydrologic Engineering Center: Hydrologic Engineering Centers River Analysis System (HEC-RAS), available at: http://www. hec.usace.army.mil/software/hec-ras/hecras-hecras.html, access: 5 March 2007, 2005.

IKSE, Internationale Kommission zum Schutz der Elbe: Dokumentation des Hochwassers vom August 2002 im Einzugsgebiet der Elbe, available at: http://www.ikse-mkol.org, access: 5 March 2007, 2004.

IPCC: Climate Change 2007 - Impacts, Adaptation and Vulnerability, Contribution of Working Group II to the Fourth Assessment Report of the IPCC, Cambridge University Press, New York, USA, 2007.

Kidson, R., Richards, K. S., and Carling, P. A.: Hydraulic model calibration using a modern flood event: The Mae Chaem River, Thailand, Proc. PHEFRA Workshop, Barcelona, Spain, Oct 2002.

KLIWA: Report on the national project KLIWA (Klimaveränderung und Wasserwirtschaft), available at: http://www.kliwa.de, ac- 
cess: 10 March 2004, 2003.

Königliches Ministerium des Innern: Verwaltungsbericht der Königlichen Ministerialabteilung für den Strassen- und Wasserbau für die Rechnungsjahre vom 1. Februar 1893/94 und 1894/95, Stuttgart, Germany, 1896.

Königliches Ministerium des Innern: Verwaltungsbericht der Königlichen Ministerialabteilung für den Strassen- und Wasserbau für die Rechnungsjahre vom 1. Februar 1897/98 und 1898/99, Stuttgart, Germany, 1901.

LfU, Landesanstalt für Umweltschutz Baden-Württemberg: Abflusskennwerte in Baden-Württemberg, Oberirdische Gewässer/Gewässerökologie 94, CD-ROM, Karlsruhe, 2005.

Ludwig, K. and Bremicker, M. (Eds.): The Water Balance Model LARSIM - Design, Content and Applicationes, Freiburger Schriften zur Hydrologie, 22, 130 pp., 2006.

O'Conner, J. E. and Webb, R.: Hydraulic modelling for paleoflood analysis, in: Flood geomorphology, edited by: Baker, V. R., Kochel, R. C., and Patton, P. C., Wiley, New York, 393-402, 1987.
Payrastre, O., Gaume, E., and Andrieu, H.: Use of historical data to assess the occurrence of floods in small watersheds in the French Mediterranean area, Adv. Geosci., 2, 313-320, 2005, http://www.adv-geosci.net/2/313/2005/.

Pohl, R.: Auswertung von Wasserspiegellagenberechnungen mit historischen Datensätzen für die Hochwasseranalyse, Wasserwirtschaft, 5/2007, 16-20, 2007.

Sauer, V. B., Curtis, R. E., Santiago, L. R., and Gonzales, R.: Quantifying flood discharges in mountain tropical streams, Int. Symp. Trop. Hydrol. and 2nd Caribbean Islands Water Resour. Congr. Proc., 104-108, 1984.

Statistisch-Topographisches Bureau: Württembergische Jahrbücher für Statistik und Landeskunde, Stuttgart, Germany, 1883.

Thorndycraft, V. R., Benito, G., Rico, M., Sopeña, A., SánchezMoy, Y., and Casas, A.: A long-term flood discharge record derived from slackwater flood deposits of the Llobregat River, NE Spain, J. Hydrol., 313, 16-31, 2005.

Thorndycraft, V. R., Barriendos, M., Benito, G., Rico, M., and Casas, A.: The catastrophic floods of AD 1617 in Catalonia (northeast Spain) and their climatic context, Hydrol. Sci. J., 51, 899-912, 2006. 